\title{
Yin-Yang Theory, the Human Organism, and the Bai hu tong: A Need for Pairing and Explaining
}

\author{
Paul U. Unschuld
}

\begin{abstract}
This paper discusses some terminological consequences of the acceptance of a seemingly allpervasive yin yang dualism by ancient Chinese naturalists, with a focus on the origin of certain technical terms introduced to designate morphological and functional items in the emerging Chinese medicine. These terms were selected from words not originally linked to morphological and physiological notions. They served as metaphors to illustrate both function and the yin yang nature of the items they were chosen to designate. How to translate these terms into Western languages is a complex issue not sufficiently discussed among philologists.

In 79 CE, the historian Ban Gu 班固 (32-92) published the Bai hu tong 白虎通, based on contributions by an unknown number of participants in one of the first documented meetings of intellectuals in antiquity. Chapter 8 offers a discourse on the meaning of qing 情, 'emotion', and xing 性, 'moral disposition'. Two terms were available that had been in long use in this arena of meanings, albeit without a clear-cut distinction along the lines of a yin-yang categorisation. No metaphors were required here. Rather, a redefinition of qing 清 and xing 性 was required to assign a yang nature to the former and a yin nature to the latter.

The Bai hu tong is a telling example of a continuing heterogeneity of explanatory models in early Chinese life sciences. The following discussion offers an impression of the merger of what may originally have been a neutral attempt at a dualistic categorisation of all phenomena in terms of two natural categories of yin and yang with another doctrine. The second clearly valued yang phenomena more highly than yin phenomena and applied this distinction to more and less desirable moral categories. Also, the Bai hu tong offers evidence of different metaphorical usages of the term $f u$ 府 in physiological theory from as early as Han times. To the older meaning: 'short-term storage facility' a second meaning of 'palace' was added. The question of an adequate translation of such terms in modern languages is worth further thought. ${ }^{1}$
\end{abstract}

\section{Keywords}

Bai hu tong, Yin-yang theory, Chinese medical terminology, translation

${ }^{1}$ An earlier version of this paper was read by Hermann Tessenow and two anonymous reviewers. I am most grateful for their valuable suggestions to clarify my arguments. 


\section{Yin-yang categorisation and the choice of metaphors}

At some time in the late Zhou era, i.e. around the third century BCE, an established understanding involving a pairing of selected phenomena in the natural world appears to have been extended to an interpretation of the entire universe. This was based on the idea that such a pairing constitutes a basic structural principle linking all phenomena. Knowledge of this structural principle, philosophers seem to have assumed, enabled them to explain, if not predict, eternal change involved in the coming into being, maturation, decline, and passing away of all possible types of things, as well as to interpret the nature of the interactions among them.

Possibly preceded by terminological juxtapositions such as xiong 雄, 'male', and $c i$ 䧳, 'female', or pin 牝, 'female', and $m u$ 牡, 'male', eventually the categories of yin 陰, 'dark side of a mountain', and yang 陽, 'sunny side of a mountain', appeared best suited to express this notion to late Zhou and early Han dynasty Chinese naturalists. Henceforth, a presumed all-pervasive dualism was defined with these two terms, and an ever more complicated yin-yang doctrine emerged.

In the history of natural scientific theory, no matter what observations may have stimulated the creation of a theory, facts and phenomena offering supporting evidence may prove very limited. By definition, though, theories are meant to explain not only visible phenomena but also those processes that remain unseen by the human eye. A theory is a tool of the human intellect to open a window on a segment of an assumed reality concealed in a black box called existence. As a consequence, a descriptive argumentation, such as: 'day, light, movement are yang; night, darkness, standstill are yin', is amended by an associative argumentation, to the effect that: 'if there is $q i$ in the human organism, there must be $y a n g q i$ and $y i n q i$. This is where the autodynamism of a theory takes flight. It is assumed that phenomena of whose existence one is convinced, but which may not be provable as a part of everyday experience, can be subsumed under the same tenets as those facts and phenomena observed with the human eye. In modern science experiments are conducted to prove or disprove such assumptions. In ancient science such a corrective was not yet available. Plausibility was sufficient proof of truth.

Yin-yang categorisation is a case in point. Night, darkness, stillness, females, and many other phenomena appeared to ancient Chinese naturalists to be associated with the contrasting day, light, movement, males, etc., in a yin and yang dualism. Soon enough these early scholars must have found themselves confronted with the problem of how to extend their theory of an all-pervasive yin-yang dualism to regions where opposites were not as easily distinguishable 
as day is from night. Human internal morphology and physiology are such regions. When the yin-yang categorisation was applied to the human organism, its outer and inner morphology and its presumed functions required firstly a division into yin and yang units, and secondly an appropriate nomenclature to make this division visible and, perhaps even more importantly, appear natural. No evidence is available today to suggest a pre-Han categorisation of the internal organs into two distinct groups. Hence, Chinese naturalists who were convinced of the existence of two distinct groups of organs in the human body, i.e., one yin group and one yang group, were unable to resort to long-established precedents in designating these two groups. Rather, they were forced to choose for themselves two terms that responded to two separate requirements. First, terms chosen must fit the designated unit, in this case organs like the heart, lungs, stomach, large intestine, etc. That is, to categorise the organs, two terms had to be selected, both of which reflected, at least to a certain degree, the physiological functions assigned to these organs as a whole. In addition, terms were to be pairs that offered, in their juxtaposition, some hint at a yin and yang nature of the two sub-groups among the organs. Both of these demands required the use of metaphors, that is, of terms lending themselves to convey a meaning to the newly conceptualised categories from an area of meanings well-known to at least a broader educated elite. ${ }^{2}$ The choice of terms may have been further complicated by the fact that at some point in time the yang category of all existence was valued higher than the yin category, at least in the world view of some early Chinese philosophers.Several pairings found in ancient Chinese morphology and physiology appear to owe their existence and designation to such requirements. Dualistic terms distinguishing between day and night, light and darkness, and male and female were well established in ancient Chinese long before the advent of yin-yang categorisation. In contrast, terms widely used in later medicine like zang 藏 and $f u$ 府, shu 俞 and $m u$ 募, ying 营 and $w e i$ 衛, and ren 任 and $d u$ 督, are designations transferred from their conventional subjects of reference to a new reference that makes sense only in the context of a yin-yang doctrine.

The translation of such terms into Western languages poses difficulties. In ancient Greece as in ancient China, naturalists resorted to metaphorical usages of words known to all members of their language community to indicate their understanding of the shape or function of a certain morphological unit, or of intangible phenomena. ${ }^{3}$ For example, the Greek word for woven tissue, histos,

\footnotetext{
2 Haverkamp, 1990.

3 For the most recent survey of existing theories of metaphors in the formation of ancient Greek medical terminology to date, and the introduction of a new category of 'empirical metaphors', see Richter, 2009.
} 
was adapted to signify certain cell structures that we still call body 'tissue' today. However, it is not as simple as that. Originally, histos had signified the mast of a ship. Because a mast carried a sail made of tissue, the meaning of histos was extended to include 'tissue'. There was no question when Chinese linguists discussed the proper translation of the European term 'histology', that they referred to the secondary meaning of histos, not to the primary meaning. Hence Chinese equivalents of the Western medical terminology of the histo-family use the binomial $z u$ zhi 組織 to convey literally the image of a 'woven tissue'. Presumably in choosing a Chinese term for histo-, no one would have even thought of returning to its original meaning: 'ship mast'.

To translate ancient Chinese metaphorical medical terms into a modern Western language requires a similar decision-making process. The meanings assigned to a word over time should be reflected in the target language. The Chinese term jing 經 is as good an example as histo-. The metaphorical significance that has helped this technical term to move from the realm of weaving into numerous and diverse areas of reference is that of a 'warp thread'. What, one may ask, may have prompted ancient Chinese intellectuals, contributing to the expansion of their vocabulary, to choose 'warp thread' to refer to major rivers, major texts, and also to the major passage-ways of blood and $q i$ in the human organism?

No explicit reflection on this question was recorded in Chinese antiquity. One may assume, though, that the basic metaphorical value of a warp thread is its function of holding the weft, that is, of supporting all the many threads that together form the main weave of a tissue over the warp. Without the warp a tissue breaks down, whereas a single weft thread, or even several weft threads, may loosen or be lost and the tissue will hold nevertheless. But the warp is basic: if it is destroyed, the tissue loses its essential support, and thereby its structure. A warp is thus an element that holds together what is supposed to exist for a long time. One may regard Chinese literature, that is, Chinese written culture, as a tissue. This tissue is woven around certain essential texts that should be in place forever to keep all the fine wefts in place that provide the culture tissue with its many facets and colours. Perhaps it was this reference that led ancient Chinese intellectuals to select the character jing 經 as signifier of those 'classical' texts that they intended would provide Chinese literature, and through it Chinese culture, with its ever unchanging identity. To translate jing 經 as 'manual' is to miss the point of this metaphorical transfer. 'Canon' is not suitable either as it evokes notions of a doctrine that has been defined as orthodox by a religious body and these connotations are not necessarily included in the metaphorical use of jing 經. The European 'classic' is a secular term. Classic texts, like classical music, are culture products that are termed 
'classic' because it is believed that they will survive short-term changes in fashion and preference. They are assumed to be capable of lasting forever. They guarantee the continuation of certain basic values. This may be the idea behind the term jing 經 in titles such as Yi jing 易經, 'Classic of Change', Huangdi neijing 黄帝内經 (The Yellow Thearch's Inner Classic), and the Shen nong bencao jing 神農本草經 (Shennong's Classic of Materia Medica).

Similarly, much ancient Chinese agriculture would have been inconceivable without the irrigation systems fed by rain or, even more reliably, water diverted from rivers. The large rivers of China take their course through the land like warp threads supporting a tissue. Without these large rivers, agriculture, and therefore life, would hardly exist. Also, rivers connect different regions as means of transportation for men and goods. The metaphorical use of jing 經 appears quite suitable to express this basic notion of dependence.

Finally, there is the use of jing 經 in human physiology. The origin of the ancient Chinese concept of two opposite systems of jing 經 in the right and in the left half of the human body is unknown. As they have no verifiable morphological substratum, the concept must be the result of a projection, but the source of this projection has not been identified. In general, notions of assumed morphological structures or physiological/pathological functions in the human organism that have no morphological correlate, or at least remain invisible to the human eye, are projections of phenomena experienced in the environment of human existence. Because such facts exist externally, it is plausible that they are presumed to also exist internally. The external facts that may have stimulated the concept of two opposite and separate irrigation systems in the human body are unknown, but the major interconnecting passageways of these two systems were named: 'jing mai 經脈'. In an abbreviated version of this compound, they are simply called 'jing 經'. They run through the body vertically and they are the 'mains' for the constant flow of $q i$ and blood. The reason for choosing the term jing 經, to name them may lie either in their resemblance to the large rivers of China, or because they can be compared, once again, with a warp. That is, the jing 經 keep the organism alive much as the warp threads hold a tissue together. ${ }^{4}$

Here we need to ask ourselves how far we wish to go in recreating the world of images guiding ancient Chinese naturalists in describing the world. The Mawangdui silk manuscripts of 167 BCE speak of eleven mai 脉 without a notion of an interconnection among these structural elements. The idea of a permanent flow had not yet originated. A translation as 'vessel' appears

\footnotetext{
${ }^{4}$ On medical notions of human physiology and pathology as projections, see Unschuld 2009.
} 
appropriate because a vessel is a container. Although in a non-physiological context a Western reader may not, upon hearing the word 'vessel', primarily imagine a tube, because we have been influenced by the idea of 'blood vessels' to such an extent that 'vessel' is acceptable here. The point is that 'vessel' does not immediately invoke an image of flow.

The concept of jing 經 is different since the jing 經 were considered not only to hold blood and qi, but to pass these two vital substances through the human body. To translate a Chinese sentence like: 'The body has twelve jing' as: 'The body has twelve warp threads' makes no sense. Presumably, the term jing 經 in ancient Chinese physiology was not chosen to recreate the image of warp threads holding the body like a tissue, but to signify a system of passage ways of blood and qi. In the seventeenth century, Andreas Cleyer (16341697/8) resorted to Latin via, 'way', when he spoke of what Joseph Needham, in the mid-twentieth century, called 'tracts'. ${ }^{5}$ These are translations based on the assumed function of the jing 經; 'via' and 'tract', are not meant to reflect the original metaphorical sense of warp. In fact, the Lun heng, a text not much later than the earliest appearances of jing 經 in Chinese physiology, uses it in the sense of 'small path', and 'vertical'. In my translations of ancient Chinese medical texts, I have chosen 'conduit' as a suitable English equivalent; perhaps to speak of 'vertical conduits' or 'main conduits' would come even closer to the meaning intended by the ancient authors.

It seems entirely understandable then that no one ever has repeated the primary metaphorical significance of the word jing 经 in an English translation. Classic texts, major rivers, and physiological conduits can be etymologically traced to the notion of 'warp threads', but the uninitiated reader of English translations of Chinese texts that speak of 'classics', 'rivers', and 'conduits' does not necessarily need to be aware of this historical background to fully understand the meaning of the original Chinese text.

Does this apply to all ancient metaphors? Should we forget about etymology and always resort to translations reflecting secondary levels of meaning? Here we return to the yin-yang pairings in ancient Chinese physiology: $z a n g$ 藏 and $f u$ 府, shu 俞 and $m u$ 募, ying 营 and wei 衛, ren 任 and $d u$ 督. Like the jing 經 in the sense of 'conduits' these eight terms refer to ideas not known in physiology outside of yin-yang categorisation. Day and night are constructs found in virtually every language, like male and female. In contrast, $z a n g$ 藏 and $f u$ 府 are culture-bound divisions of human organs. It is only in the context of ancient Chinese physiology that a conceptual division of lung, heart, spleen, liver, and kidneys as zang 藏 and small intestine, large intestine, stomach, gall, urinary bladder and triple burner as $f u$ 府 is meaningful. The

${ }^{5}$ Cleyer 1682, passim. Lu and Needham 2002, passim. 
same applies to the conceptual division of needle insertion holes on the back as $s h u$ 俞 and those on the chest as $m u$ 募, of one type of protective $q i$ as ying 营 and another as wei 衛, and of a conduit passing on the back as $d u$ 督 and another on the front as ren 任. Without the claim, characteristic of the yin-yang doctrine, of a pervasive dualistic nature of the entire universe these four pairings would not have been recognised. Their translation into English has seen different approaches.

The pairing of zang and $f u$ is rendered by various Chinese and Western authors as 'zang and fu organs', 'viscera and bowels', 'solid and hollow organs', 'treasury and storehouse', among other translations. The shu and mu needle insertion holes on the back and front of the human body have been rendered as 'transport points vs. alarm points', 'stream points vs. front- $M u$ points' and 'Shu-points vs. collecting points'. The ying and wei qi have been introduced to readers of English translations as: 'yin-energy and wei-energy', 'construction $q i$ and defence $q i$ ', 'essential substance circulating in the channels and blood vessels vs. defensive energy'. Finally, the dorsal and frontal conduits $d u$ and ren have been rendered as: 'Du channel vs. Ren channel', 'governing vessel vs. conception vessel', 'governing channel vs. ren-channel'. 'governing vessel vs. controller vessel'. For the most part, the English equivalents chosen are not meant to reflect a metaphorical message included in the original Chinese terms, and one may ask indeed whether that is desirable at all.

Naturally, if an acupuncture treatment was able to produce physiological effects, these effects should be independent of the technical nomenclature guiding practitioners in their attempts at finding the appropriate insertion holes, mobilizing internal qi, etc. However, translations of ancient texts speak to at least two audiences. One is the audience of healers. Their interest, especially if they are influenced by advocates of the PR China policy of a modernisation of TCM, focuses on creating a scientific image of their healing art, and this includes a resort in English translation of traditional terminology to ancient metaphors as little as possible. On the other hand, philologists and anthropologists may prefer a social science approach in their reading of ancient texts. This entails efforts to recreate in a translation the images underlying the ancient Chinese understanding of human physiology and pathology, as it is only through an understanding of these images that the pecularities of Chinese medicine can be perceived. The resulting antagonism between 'modernists' and social scientists is difficult to overcome.

When the Chinese premier Wen Jiabao visited Charité Medical University in Berlin in February 2009, members of his entourage interested in trade relations with German medical institutions were introduced to our attempts at generating philologically serious English translations of some seminal Chinese medical classics, such as the Huangdi neijing suwen, Nan jing, etc. Eventually, 
some of the delegation members vehemently protested against what they called an illegitimate identification of modern China with the superstition of past millennia, and requested that we focus on what they called 'modernised Chinese medicine'. What is to be learned from such an outbreak of anger, reflecting the Chinese administration's attitude towards Chinese medicine, is that one should perhaps be surprised to find among English translations of ancient Chinese texts prepared by contemporary Chinese authors anything that is worth closer philological scrutiny. The official Chinese policy towards generating a list of standardised English translations of Chinese TCM terminology may be of value to practitioners of TCM and acupuncture, but it is certainly generally worthless for all those who wish to take the historical background of Chinese medicine into account in their attempts at penetrating the culture-bound characteristics of the Chinese approach to health care.

The translation of term pairings like zang-fu, shu-mu, ying-wei, and du-ren is a case in point. It is only through a literal translation, starting from their primary metaphorical message, that the culture-bound nature of ancient Chinese medical concepts is to be revealed. Hence it is understandable that those forces who wish to emphasize a timeless and cross-cultural validity of Chinese medical theory find little reward in analysing the metaphorical meaning of these pairings. Most of the English renderings quoted above obfuscate rather than clarify the origins of Chinese medical terminology.

A discussion of an appropriate English translation may begin with the pairing $s h u-m u$. These are terms signifying functions associated with needle insertion holes on the back and on the front of a patient. Earlier English renderings have identified the meaning of shu as 'to transport' and of $m u$ as 'to collect', but no author has brought these two meanings together to generate an English pairing of 'transportation holes' and 'collecting holes', or, as I prefer, 'transporter' and 'levy' holes or openings. In a translation aimed at recalling the conceptual foundations and environment of ancient Chinese medical interventions, a holistic approach intends to put every theoretical and clinical facet into place. This includes taking seriously the choice of terms by ancient authors. Shu openings are yang needle insertion holes. They are located on a person's back, and their choice reflects an attempt at including yang qualities, such as movement. Transport is movement. In contrast, $m u$ holes are located on a patient's front side. This is the yin side of the body, and the term chosen, $m u$, signifies the opposite of movement, that is, to collect and store things. This is the meaning of 'to levy'.

Similar considerations may be applied to elucidate the choice by ancient Chinese authors of the pairing $d u$ mai and ren mai for the two central conduits on the back and front. $\mathrm{Du}$ and ren are terms borrowed by Han-dynasty medi- 
cal authors from the arena of state administration. Du vs. ren is the only pairing that has been rendered in English with a complete metaphorical equivalent for some time already; as is to be expected not by Chinese but by Western authors. Birch and Felt, in Understanding Acupuncture, have chosen to use the terms 'governing vessel' vs. 'controller vessel'. My own preference is 'supervisor vessel' vs. 'controlling vessel'. In contrast to the easily identifiable yang and yin qualities of $s h u$, 'to transport', and $m u$, 'to levy' respectively, one may assume that well-established hierarchical differences between administrative positions of $d u$ and ren stimulated Han dynasty authors to select this pairing in naming two important conduit vessels.

$D u$ and ren signify tasks in an administration. Charles O. Hucker identifies $d u$ as 'most commonly signifying that without giving up his regular post, an official had been delegated to take temporary charge of another post. ${ }^{6}$ One may detect mobility, and hence a yang quality, in 'taking temporary charge of another post', but ren as the opposite can hardly be identified as a more stable position. This implies that the choice of these terms may have been led by other considerations. Rather than choosing a pairing that suggested 'movement' vs. 'non-movement' to Han dynasty readers, two administrative terms were selected that reflect different echelons in a bureaucratic hierarchy. $D u$ was definitely a higher ranking official than ren. A $d u$ could be in charge of, for example, an army division. A $d u$ was a leading position, such as a supervisor, or a general. In contrast, ren has the meaning 'to shoulder', 'to shoulder a task', 'to assume an official position'. A ren could be any lower official who was simply in charge of controlling the execution of some ordinary task.

A rendering of ren mai as 'conception vessel', a term frequently used in TCM practitioner texts, is rather difficult to accept. The general principle in choosing terms for these pairings appears to have been to select two terms from one arena of public life known to all potential future users of the terms. The two terms chosen had to be rather close in their meanings, with a difference that enabled one to associate one of the two with a yang and the other with a yin meaning. The metaphorical rationale of juxtaposing $d u$ and ren in the context of human physiology seems to have been one of acknowledging a higher rank of yang phenomena in comparison with yin phenomena.

Ying $q i$ 营氣 and wei $q i$ 衛氣 are further candidates for examination in view of this general principle. It was apparently assumed by ancient Chinese observers of the human body's health and illness that, as in social life, attacks by hostile agents on the organism could be successful or not, depending on the ability of a potential victim to defend himself. Hence military metaphors

${ }^{6}$ Hucker 1985, p. 535. 
served to provide a terminology for this projection of a social fact into the human organism. As the yin-yang doctrine claims a pervasive duality of phenomena, the organism was supposed to have at its disposal two types of protective forces, the wei qi and the ying qi. In the same way as $d u$ and ren were chosen from an identical arena of social facts, i.e., that of the administration, wei and ying were chosen from the arena of the military. Here once again the categorisation as mobile vs. immobile appears to have been the guiding principle underlying the choice of terms.

Wei and ying are both associated with military defence. Ying 营 signifies a military camp. This is a sedentary unit, staying firmly in place for an extended period of time, but to protect a city or country a successful military force also needs mobile units, which are flexible in their movements. They patrol day and night, and they can be sent here and there. They constitute the yang counterpart of the yin camps. In ancient Chinese physiology they appear to have been signified by the term wei 衛, literally meaning, 'guards'. Hence I have chosen to translate ying $q i$ as 'camp $q i$ ' and wei $q i$ as 'guard $q i$ '. A translation of ying $q i$ as 'constructive $q i$ ', as is frequently the case in TCM practitioner literature, appears questionable for at least two reasons. Firstly, because it does not offer a yin quality in comparison with the yang quality of wei, and secondly, ancient Chinese medicine at no point offers a hint that a sub-section of $q i$ is identified as carrying a specifically 'constructive' potential.

The fourth of the pairings listed above is the juxtaposition of zang 藏 and $f u$ 府. In late Zhou and early Chinese vernacular language, both terms were used to refer to what one might call places of storage, such as a granary, storehouse, or reservoir. $F u$ appear to have been places where all of the items, funds, and documents required by a bureaucracy were stored. Zang were places to hide away particularly valuable or precious items. Such a reading of nonmedical usage of the word seems to parallel the distinction provided in Su wen 11 , where the six $f u$ are said to receive the more solid $q i$ which, however, they do not store for long but soon release again. In contrast, the five zang store the finest $q i$, which they not do not readily release again.

No English terms conveniently express by means of two single words the fu-zang antagonism of short-term and long-term places of storage, that is, of transitory storage and definite storage. Zang could be translated as 'treasury' or 'depository' or, as I have chosen, 'depot' to convey the sense of long-term storage. For $f u$, though, it is impossible to find a matching term to signify what might be considered temporary storage as a yang quality in contrast to permanent storage as a yin quality. Also, during the late Zhou and early Han dynasties, the meaning of $f u$ underwent an expansion from 'short-term storage facility' to signify also venues of administration and, subsequently, a palace 
where an administrator resides. This is clearly the meaning of $f u$ in the physiology outlined in juan 8 of Ban Gu's 班固 Bai hu tong [yi] 白虎通[義] of 79 CE. 7 The text identifies the five $f u$ as gong fu 宮府, 'palaces' of the $z a n g$, evoking the notion of officials residing in the palaces. These zang officials 'rule', zhu 主, or are responsible, for example, for supplying the body with qi. It is this expansion of the meaning of $f u$ that makes it so difficult to find an English translation for the $z a n g-f u$ pairing. No pair of terms is readily available in English that might satisfy the historian of ideas in that it first reflects the primary theoretical message of zang 藏 and $f u$ 府 as a distinction of long-term and short-term storage facilities, clearly reflecting a yin-yang dualism, and also includes a hint at what appears to be a shift in the understanding of the organs when a metaphor was chosen that uses $f u$ 府 in the sense of 'palaces' housing officials acting as 'rulers'. One may speculate about a different ranking of $z$ ang and $f u$ in the juxtaposition of long-term storage vs. short-term storage. The yin-yang pairing in this metaphor appears to have been based on the contrast between long-term stability associated with zang storage vs. frequent movement and activity associated with $f u$ storage. The second metaphorical pairing of zang and fu seems to be built on a higher ranking of the former in comparison with the latter. We shall recognise this with more clarity when we take a closer look at the text of the Bai hu tong further below.

My thesis that the four parings: shu-mu, du-ren, ying-wei, and fu-zang are the result of ancient Chinese attempts at projecting an all-inclusive yin-yang categorisation on the human body and its functions, prompts the question of whether there are more pairings than these four. Could it be that jin 津 and ye 液 were understood in antiquity as a yin and a yang liquid respectively, with one of them being associated with a calmer and the other a more mobile nature? This may be worth further study.

\section{Yin-yang doctrine and redefinition of terms}

Another pairing that may owe its juxtaposition to the requirements of yinyang theory links the two characters xing 性 and qing 情. The former is commonly translated as 'nature' or 'disposition', and the latter as 'emotion' or 'affect'. The English terms, deliberately or not, seem to suggest a yin and yang quality. A 'disposition' may be categorised as a yin quality; based on the Latin root of 'ponere', to set down, it is associated with notions of stability, and long-lasting qualities. Trustworthiness, for example, is not a quality a person

\footnotetext{
${ }^{7}$ Cf. Tjen Tjoe Som 1952, p. 566 ff.
} 
acquires overnight and loses again after showing it for only a brief time. In contrast, emotions, as the Latin root 'movere', to move, in the English word indicates, signify more flexible states such as joy and anger, which do not usually last long. Joy may even turn into anger, and vice versa. That is, disposition and emotion seem to suggest a rather straightforward yin and yang categorisation. We should consider therefore whether xing 性 and qing 情 in Chinese may also be associated with such yin and yang qualities. The Bai bu tong of 79 $\mathrm{CE}$ is the place to expect an answer, and an answer is indeed given, but it contradicts what the etymology and meaning of the English terms might suggest. The relevant passage begins with the statement:

$\begin{array}{ll}\text { 性情者, } & \text { Moral dispositions and emotions, } \\ \text { 何謂也? } & \text { What do they refer to? } \\ \text { 性者, 陽之施; } & \text { Moral dispositions are manifestations of yang. } \\ \text { 情者, 陰之化也。 } & \text { Emotions are transformations of yin. }\end{array}$

A few lines further on, the author adds:

情者, 靜也, Qing [emotions] is jing [calmness].

性者, 生也, Xing [moral dispositions] is sheng [life].

In the same way as we have carved out of the English word disposition the Latin root ponere, and out of emotion the Latin root movere, the ancient Chinese author cut his terms xing 性 and qing 情 to isolate 生 and 靜 to validate a yang and a yin quality respectively. After all, sheng 生 in the sense of to give birth or bring forth, is a yang quality, and jing 靜 in the sense of quietude is a yin quality. Yin and yang are no longer (if ever they were considered as such) neutral categories that divide natural phenomena into two equal groups alternately dominating one another, like night and day or winter and summer. Instead, Yin and yang are used here to express discrimination in morality as in nature: light is better than darkness, action is better than inactivity, males are more valuable than females, moral dispositions are more fundamental than emotions.

A quotation in the Bai hu tong from an earlier text of unknown authorship, the Gou ming jue 鉤命決, discloses the rationale presumed to legitimate such a categorisation:

情生於陰, The emotions originate from the yin.

欲以時念也; One's desires, one thinks of them all the time.

性生於陽, The dispositions originate from the yang.

以就理也。 They serve to achieve structure.

$L i$ 理 signifies 'order' and 'structure', and order is what is valued most. Hence li may also be read as 'principle'. Structure and principles are basic; they are required to stay, lest chaos evolves. Yü 欲, one's desires, are temporary and 
frequently change. If $l i$ is associated with xing and yang here nevertheless, this is because the author of these lines did not consider associations with stability ( yin) vs. movement ( yang) as his rationale. He based his identification of dispositions as yang and emotions as yin on a ranking of the former over the latter, associating a yang nature with the more valuable aspects of existence, and a yin nature with those less valuable. The following statement expresses this difference even more clearly:
陽氣者仁
As for $y$ ang $q i$, this is humaneness
陰氣者貪
As for yin qi, this is greed
故
Hence,
情有利欲
emotions include profit and desires
性有仁
moral disposition includes humaneness

The Bai hu tong goes on to explain the dispositions in detail:

$\begin{array}{ll}\text { 五性者何謂? } & \text { What are the five dispositions? } \\ \text { 仁、義、 } & \text { They include humaneness, righteousness, } \\ \text { 禮、智、信也。 } & \text { propriety, wisdom, trustworthiness. } \\ \text { 仁者, 不忍也, } & \text { Humaneness is compassion }{ }^{9} \\ \text { 施生愛人也; } & \text { It tends to generate love of mankind. } \\ \text { 義者, 宜也, } & \text { Righteousness is to act appropriately. } \\ \text { 斷決得中也; } & \text { In one's decisions one always hits the point. } \\ \text { 禮者, 履也, } & \text { Propriety is conduct. } \\ \text { 復道成文也; } & \text { If one’s conduct is in accordance with the Way, one's } \\ & \text { culture is perfected. } \\ \text { 智者, 知也, } & \text { Wisdom is knowledge. } \\ \text { 獨見前聞, } & \text { One needs to take into regard only what one has heard, } \\ \text { 不惑於事, } & \text { and there will be nothing one is uncertain about. } \\ \text { 見微者也; } & \text { This way one recognises the details. }{ }^{10} \\ \text { 信者, 誠也, } & \text { Trustworthiness is sincerity. } \\ \text { 專一不移也。 } & \text { It means to be focussed, without shifting. } \\ \text { 故人生而應 } & \text { Hence if humans live to correspond to } \\ \text { 八卦之體, } & \text { the structure of the eight trigrams, } \\ \text { 得五氣以為常, } & \begin{array}{l}\text { they will be endowed with the five qi to be transformed } \\ \text { into the eternal virtues }\end{array} \\ \text { 仁、義、 } & \text { These are humaneness, righteousness, } \\ \text { 禮、智、信是也。 } & \text { propriety, wisdom and trustworthiness. }\end{array}$

\footnotetext{
${ }^{8}$ Some editions of this text have 五常, 'five eternal [virtues]', instead of 五性. This identification of the five moral dispositions as five eternal virtues is justified by a statement further down where humans living in accordance with the eight trigrams are said to receive $q i$ to be transformed into the 五常.

9 不忍, lit.: 'one cannot bear [to see the suffering of others without helping them]'. See Legge 1991, p. 202.

${ }^{10}$ Wu Zeyu (ed.), Chen Li (ed.), 1994. 吳則虞 點校, 陳立撰, 白虎通疏證, 中華書局, 北京, read 見微者也 as 見微知著也, 'one sees a detail and knows everything.'
} 
The five yang dispositions of humaneness, righteousness, propriety, wisdom, and trustworthiness, are to be compared with the six yin emotions, as identified by the Bai hu tong:

$\begin{array}{ll}\text { 六情者, } & \text { The six emotions, } \\ \text { 何謂也? } & \text { which are they? } \\ \text { 喜、怒、哀、 } & \text { Happiness, anger, sadness, } \\ \text { 樂、愛、惡 } & \text { joy, love, aversion, } \\ \text { 謂六情, } & \text { these are the six emotions. } \\ \text { 所以扶成五性 } & \text { They are to support and perfect the five dispositions. }\end{array}$

The final sentence should not come as a surprise. The author of the Bai hu tong considers the five dispositions as basic, and he acknowledges the six emotions as necessary to support and perfect one's dispositions. That is to say, the five dispositions of humaneness, righteousness, propriety, wisdom, and trustworthiness require the six emotions to show and be applied in one's daily activities.

The Bai hu tong then goes a step further and offers a physiological model of the interdependence of dispositions ( yang) and emotions ( $y$ in), locating the former in the body's zang 藏, i.e. 'depots', and the latter in the body's fu 府, i.e., 'palaces'. Here now we encounter the different valuation of $z a n g$ and $f u$ indicated above. It flatly contradicts the yin-yang categorisation of zang and fu in medical literature. The author of the Bai hu tong had no intention of contributing to a medical discourse. Rather, he used physiology to validate the Confucian system of moral values, and to achieve this reversed yin and yang categorisation of the zang and $f u$.

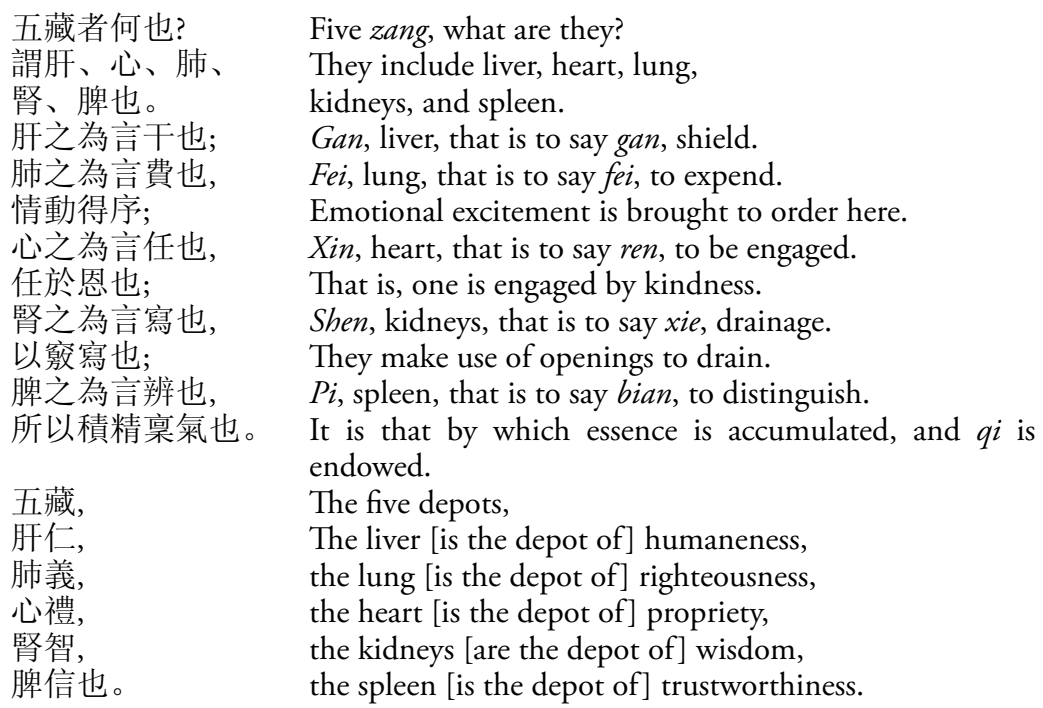


肝所以仁者何? Why is it that the liver has the humaneness?

肝, 木之精也; The liver is the essence of wood.

仁者, 好生。 Humaneness is the love of life.

東方者陽也， The East is yang.

萬物始生,

故肝象木,

This is where the myriad beings come to life.

Hence the wood is the image of the liver.

色青而有枝葉。 Its colour is green, and it has branches and leaves.

目為之候何? Why is it that the eyes are its sense organ?

目能出淚 The eyes can shed tears,

而不能內物, but they are unable to ingest anything.

木亦能出枝葉 Wood likewise is able to produce branches and leaves,

不能有所內也。 it is unable to ingest anything.

肺所以義者何? Why is it that the lung has the righteousness?

肺者, 金之精; The lung is the essence of metal.

義者, 㒬決。 Righteousness is decision making.

西方亦金， The West is metal too.

成萬物也， It brings the myriad things to maturity. ${ }^{11}$

故肺象金， Hence the metal is the image of the lung.

色白也。 Its colour is white.

鼻為之候何? Why is it that the nose is its sense organ?

鼻出入氣, The nose lets out and takes in qi.

高而有憿, It is elevated and has openings.

山亦有金石累積, Mountains too have metals and stones accumulated.

亦有孔穴, And they too have holes.

出雲布雨

以潤天下,

雨則雲消,

Clouds leave from here and spread rain

to moisten the land under heaven.

鼻能出納氣也 The nose is able to let out and take in $q i$.

心所以為禮何? Why is it that the heart brings forth propriety?

心, 火之精也。 The heart is the essence of fire.

南方

尊陽在上， the yang is revered [by placing it] above,

卑陰在下,

禮有尊卑,

故心象火,

the yin is regarded lowly [by placing it] below.

The rites distinguish between elevated and inferior status.

色赤而銳也,

Hence fire is the image of the heart.

人有道尊,

Its colour is red, and it is pointed.

天本在上,

Man has the Way to revere.

故心下銳也。

His base is heaven above him.

耳為之候何?

Hence the lower part of the heart is pointed.

Why is it that the ears are its sense organ?

11 Wu Zeyu, 1994, followed the corresponding passage in the Tai ping yu lan and changed to: 西方亦金, 殺成萬物也, 'the West is metal too. It kills and brings to maturity the myriad things.' 


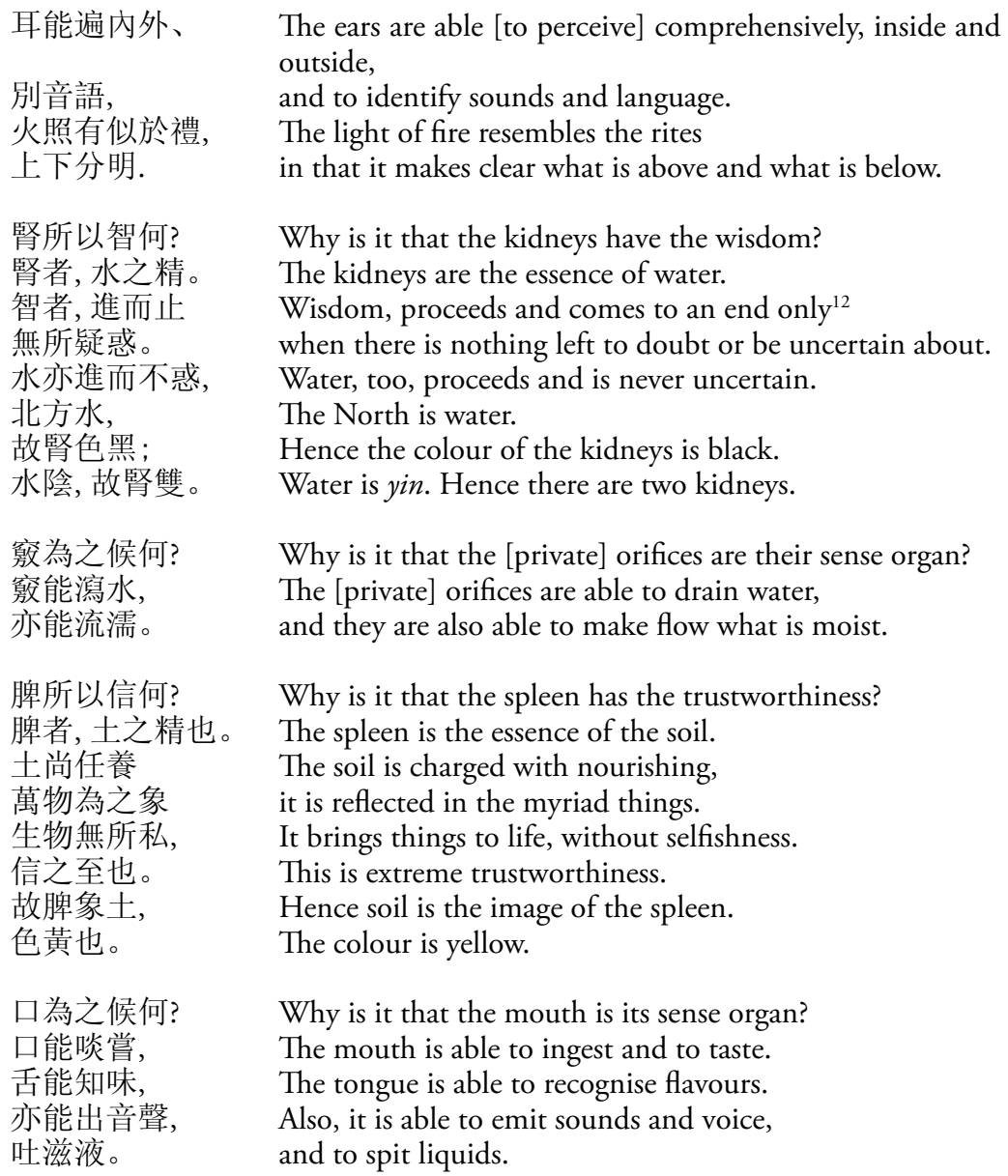

The metaphorical language chosen by the author of the Bai hu tong places moral dispositions and emotions into the theoretical framework of yang and yin dualism. It assigns a priority to yang and to the dispositions, while at the same time acknowledging the depots, storing the moral dispositions, as residents of 'palaces' where they 'rule', $z h u$ 主. That is, where they accomplish certain tasks, such as drainage, or, on the basis of 'humaneness', judgment. The metaphorical meaning of zang as a yang facility storing yang moral dispositions is somewhat modified in that the $z$ ang themselves are housed in the $f u$, identified here as gong fu 宮府, 'palaces.'

12 智者, 進而止: Wu Zeyu 1994 has: 智者進止, 'wisdom whether advancing or stopping, has nothing to doubt or be confused about.' 
六府者, 何謂也?

謂大腸、小腸、

胃、膀胱、

三焦、膽也。

府者, 謂五藏宮府也。

故禮運記曰:

‘六情所以扶成五性也。”

胃者, 脾之府也，

脾主稟氣;

胃者, 穀之委也,

故脾禀氣也

膀胱者, 腎之府也。

腎者, 主瀉,

膀胱常能有熱,

故先決難也

三焦者,包絡府也。

水穀之道路,

氣之所終始也。

故上焦若憿,

中焦若編,

下焦若瀆。

膽者, 肝之府也。

肝者, 木之精也,

主仁。

仁者不忍,

故以膽㫁也,

是以肝膽二者 ${ }^{14}$

必有勇也。

肝膽異趣,

何以知相為府也?

肝者, 木之精也, 木之為言牧也, 人怒無不色青
Six $f u$, what does that mean?

They include large intestine, small intestine, stomach, bladder,

triple burner, and gall bladder

$F u$ is to say: the palaces of the five $z a n g$.

Hence the Li yun ji states: ${ }^{13}$

'the six emotions, they are to support and perfect the five dispositions.'

The stomach is the palace of the spleen.

The spleen governs the endowment with $q i$

The stomach is in charge of the grain.

Hence the spleen endows with $q i$.

The bladder is the palace of the kidneys.

The kidneys govern drainage.

The bladder is able to always have heat.

Hence it is the first to dissolve [items] difficult [to digest].

The triple burner is the palace of the enclosing network.

It is the passage way of liquid and solid food.

It is the end and beginning of $q i$.

Hence, the upper burner resembles an orifice.

The central burner resembles a plait.

The lower burner resembles a ditch.

The gall bladder is the palace of the liver.

The liver is the essence of wood.

It governs humaneness

Humaneness is compassion.

Hence it relies on the gall for decision-making.

This is why both liver and gall

must possess courage.

Liver and gall differ in their inclinations,

How can one know that the latter is the palace of the former?

The liver is the essence of wood.

$M u$ [wood] is to say $m u$ [shepherd].

When a person is angry, he will be green all over,

13 This may be the chapter Li yun of the $L i j i$. However, I have been unable to locate this passage in the received text of the $L i j i$ 禮記.

14 是以肝膽二者: Wu Zeyu changed to: 是以仁者, 'this is why humaneness must go along with courage.' 
目腋張者,

是其效也。

小腸、大腸,

心肺之府也,

主禮義,

禮義者有分理,

腸之大小相承受也。

腸為心肺主，

心為支體主,

故為兩府也。

目為心視,

口為心談,

耳為心聽,

鼻為心嗅,

是其支體主也。 and his eyes and armpits will be extended.

That is the result of this.

Small intestine and large intestine

are the palaces of heart and lung.

They govern propriety and righteousness.

Propriety and righteousness have principles of

discrimination.

The large and the small intestines receive from each other.

The intestines are in charge for heart and lung.

The heart is in charge for the entire body. ${ }^{15}$

Hence [the intestines] constitute two palaces.

The eyes see for the heart.

The mouth speaks for the heart.

The ears hear for the heart.

The nose smells for the heart.

This is how it governs for the entire body.

Returning to the initial issue addressed in this paper, xing 性 and qing 情 appear to be a further example of pairings resulting from the yin-yang doctrine's claim of universal dualism. However, the choice of terms, and the selection of metaphors, may not have been as simple as in the cases of $s h u$ and $m u$ points, and of ying and wei qi. Dispositions and emotions have meanings that reach deep into Confucian conceptions of social structure and stability. Notions of a yin-yang equilibrium in nature required to be adapted to the moralists' notion of yang priorities. What may appear as an early example of an intellectual squaring of a circle was achieved by means of a complicated language structure and by bringing together different metaphorical and theoretical discourses available at the time.

Xunzi 荀子 (born ca. 312 BCE), in his section Zheng ming 正名, 'Rectification of Names', stated 性之好惡喜怒哀樂謂之情, 'The likes and dislikes, delights and angers, griefs and joys of one's disposition are called emotions.' Yü Yüe 俞樾 (1821-1907), commenting on a statement by Mengzi 孟子 (372289), pointed out
蓋性情二字
在後人言之
Now, as for the two characters xing and qing,
則區以別矣,
if we speak of people in later times,
而在古人言之 they distinguished between them.
則情即性也,
However, if we speak of people in ancient times,
for them qing was identical with $x i n g .{ }^{16}$

\footnotetext{
15 心為支體主: I follow Wu Zeyu, 1994, who has replaced 皮體 here with 支體. This is in accordance with the phrase six lines further on.

${ }^{16}$ Yu Yue 2002.
} 
Here one of the most famous commentators of the ancient philosophers gives an example of the pairing we have hypothesised above. If we follow his argument, xing 性 and qing 情 were used interchangeably at one time before they were assigned different meanings later on. It may well be that these assignments followed the claim of the yin-yang doctrine to see dualism in all phenomena. As the Bai hu tong shows, the distinction between and subsequent pairing of xing 性 and qing 情 may have permitted yin-yang theorists to extend their claim to the relationship between dispositions and emotions.

\section{Conclusion}

The pairing of characters with originally closely related, if not identical, meanings is a consequence of the acceptance of the yin-yang categorisation as universally valid. Such pairing constituted a deliberate act. Ancient naturalists were convinced of the existence of an all-pervasive dualism and therefore required symbols to signify the yin and yang nature of phenomena. In many cases the terms yin and yang sufficed as markers, for instance when texts spoke of yin qi and yang qi. However, in some cases specific terms were chosen to signify yin and yang opposites. These terms may have been selected for their inherent metaphorical value, as appears to be the case for $z$ ang 藏 and $f u$ 府, $s h u$ 俞 and $m u$ 募, ying 营 and wei 卫, and ren 任 and $d u$ 督. Others, including xing 性 and qing 情, were not imposed as metaphors from outside to lend their original meaning to phenomena not known under these names before. Rather, they seem to have signified the phenomena in question without yinyang categorisation initially, and were assigned yin and yang values later, during the course of the construction of an encompassing theorisation of the universe.

\section{References}

Andreas Cleyer, Specimen Medicinae Sinicae, Frankfurt, 1682, passim.

Haverkamp, A. (ed.) 1990, Theorie der Metapher, Darmstadt: Wissenschaftliche Buchgesellschaft.

Hucker, C. O. 1985, A Dictionary of Official Titles in Imperial China. Stanford, CA: Stanford University Press.

Legge, J. 1991, The Chinese Classics, Vol. II. The Works of Mencius, Bk. II, Part 1, Chapter 6. Taipei: SMC Publishing Inc.

Lu Gwei-Djen and Joseph Needham, 2002, Celestial Lancets: A History and Rationale of Acupuncture. London: RoutledgeCurzon, passim.

Richter, S. A. 2009, Metaphorische Gedankenstrukturen in der Entstehung der medizinischen Fachsprache in Europa, MD dissertation, Munich University. 
Tjen Tjoe Som (trans./ed.) 1952, Po Hu T'ung. The Comprehensive Discussions in the White Tiger Hall, Leiden: Brill.

Unschuld, P. U. 2009, What is Medicine? Western and Eastern Approaches to Healing. Berkeley and Los Angeles: University of California Press.

Wu Zeyu (ed.), Chen Li (ed.) 1994, Bai hu tong shu zheng, Beijing: Zhonghua shuju.

Yu Yue 2002, 俞栰, Qun jing ping yi, Meng zi, 2, 群經平議・孟子二. Shanghai gu ji chu ban she 上海古籍出版社, Shanghai. 